\title{
Postoperative Investigations Resulting in Cost Reduction in Oncological Patients Undergoing Major Abdominal and Pelvic Surgery
}

\author{
Virgiliu Mihail Prunoiu, Marian Augustin Marincaș, Sînziana Ionescu, Eugen Brătucu \\ "Carol Davila" University of Medicine and Pharmacy, Bucharest, Romania \\ $1^{\text {st }}$ General and Oncological Surgery Clinic, "Al. Trestioreanu" Oncology Institute, Bucharest, Romania
}

Corresponding author:

Marian Augustin Marincaș, MD

252 Soseaua Fundeni, sector 2

Bucharest, Romania

E-mail: marian_marincas_11@yahoo.com
Received: 8.11.2017

Accepted: 6.12 .2017

\section{Rezumat}

Investigații postoperatorii cu impact în reducerea costurilor la pacientul oncologic, în chirurgia abdomino-pelvină majoră

Obiectiv: Costurile în creştere în domeniul îngrijirii sănătății sunt de interes tot mai mare şi un factor major care afectează costurile de spitalizare sunt complicațiile postoperatorii. Complicatiile după Interventiile Chirurgicale Abdominale Majore (ICAM) sunt asociate cu o morbiditate şi mortalitate crescută. În acest studiu sunt estimate costurile îngrijirilor postoperatorii asociate cu complicatiile.

Metodă: Noi am efectuat un studiu retrospectiv pe 254 de pacienți internați în Clinica I de Chirurgie Generală şi Oncologică a Institutului Oncologic din Bucureşti, care au suferit ICAM. Au fost analizate costurile totale de spitalizare, complicațiile şi tratamentul efectuat.

Rezultate: Pentru un pacient care a suferit ICAM, costurile medii pentru intervenția chirurgicală, fără complicații, sunt de 5.791,3 lei şi ajung la o medie de 20.806 lei după complicații majore.

Concluzie: Rezultatele oferă o perspectivă asupra costurilor de spitalizare la pacienții oncologici operați. Complicațile apar la $20,86 \%$ dintre pacienții care au suferit ICAM şi reprezintă $50 \%$ dintre costurile totale de îngrijire. Stabilirea şi aplicarea unui protocol care vizează diagnosticarea şi tratamentul precoce al complicațiilor specifice ar putea duce la o scădere a morbidității şi a mortalității, dar şi al costurilor de spitalizare.

Cuvinte cheie: chirurgia oncologică genitală şi digestivă, complicații postoperatorii, costuri spitalizare pacienți 


\section{Abstract}

Aim: Rising costs in health care are of progressively growing interest and a major factor affecting hospitalization costs is represented by postoperative complications. Complications of Major Abdominal Surgery (MAS) are associated with increased morbidity and mortality. This study estimates the costs of postoperative care associated with complications.

Material and Methods: We performed a retrospective study on 254 patients admitted to the $1^{\text {st }}$ General and Oncological Surgery Clinic of the Bucharest Oncology Institute who were submitted to MAS. The total hospitalization, complications and treatment costs were analysed. Results: For a patient undergoing MAS, the average costs for surgery without complications are 5,791.3 RON and reach an average of 20,806 RON after major complications.

Conclusion: The results provide insight into the costs of hospitalization for oncology patients submitted to surgical interventions. Complications occur in $20.86 \%$ of patients undergoing MAS and account for $50 \%$ of total care costs. Establishing and implementing a protocol aimed at early diagnosis and treatment of specific complications could lead to a decrease in morbidity and mortality, as well as of the costs of hospitalization.

Key words: genital and digestive oncological surgery, postoperative complications, patient hospitalization costs

\section{Introduction}

Rising costs in health care are of progressively growing interest and a major factor affecting hospitalization costs is represented by postoperative complications. Major abdominal and pelvic surgery (MAPS) can be defined as surgical oncological interventions performed in the genital area (uterine, cervical, ovarian tumours) and abdominal area (gastric, hepatobilio-pancreatic, colorectal tumours). Digestive surgery involves anastomoses and / or stomas.

Complications arising from major abdominal surgery (genital and digestive) may be associated with a morbidity between 3.7 and $35 \%$, and mortality is increased (1.4-12.3\%). Data from the literature show that postoperatively complications may occur in a percentage between $12.3 \%$ and $20 \%(1,2,3)$. Complications require intensive care and close monitoring of patients. Increased morbidity and mortality imply an increase in the number of days spent in ICU (anaesthesia and intensive care unit) and in the total days of hospitalization, resulting in an increase of over $50 \%$ in hospital costs (1).

\section{Material and Method}

The classification of postoperative complications was done in according with the one proposed by Dindo-Clavien, which divides complications into minor and major $(4,5)$. Grade I and II minor complications require non-invasive treatment, while for grade III and IV major complications invasive treatment under local or general anaesthesia (surgical reintervention, CT guided drainage etc.) and / or readmission and monitoring in ICU are required, which also generated an increase in hospital resources requirement (sanitary materials, medication, additional paraclinical and imaging investigations etc.). Our study estimates the costs of postoperative care associated with complications.

We performed a retrospective study, conducted between August 2015 and December 2016, on 254 patients who underwent major abdominal and pelvic surgery (MAPS). The analysis was carried out in the $1^{\text {st }}$ General and Oncological Surgery Clinic of "Al. Trestioreanu" Oncology Institute in Bucharest. 
The laboratory investigations performed to diagnose and monitor complications were:

1. CBC (complete blood count) - the number of leukocytes was monitored by increasing blood testing frequency;

2. CRP (C-reactive protein) - value increase and whether or not it returned to normal;

3. Measurement of leukocyte count from peritoneal fluid (performed only for patients with digestive sutures).

The additional imaging investigations performed to diagnose and monitor complications were:

1. Abdomino-pelvin ultrasound exam;

2. Chest \pm abdomen X-ray;

3. Chest \pm abdomen \pm pelvis contrast CT (oral and intravenous).

It should be mentioned that interventional radiology was not used, and patients who, according to clinical and paraclinical data, required surgery, were submitted to reinterventions (11 patients - 35.48\% of those with major complications).

Thus, we analysed:

- total hospitalization costs;

- complications and treatment costs.

Costs were determined by:

- Number of days of hospital stay (ward $+\mathrm{ICU} \pm$ reinterventions);

- Laboratory investigations;

- Imaging investigations.

The costs for investigations at the Bucharest Oncology Institute (approved by the Bucharest Health Insurance House) were of:

- $\mathrm{CBC}-19 \mathrm{RON}$;

- CRP - 12 RON;

- Leukocyte count from peritoneal fluid -9 RON;

- Pulmonary/abdomen X-ray - 32 RON;

- Abdomen + pelvis ultrasound exam - 90 RON;

- Chest/abdomen contrast CT - considered the most eloquent imaging exam 290/290 RON.

Data provided by the Statistics Department of the Bucharest Oncology Institute were used for cost analysis. Costs of complications were tracked for patients who exceeded the average hospital stay, namely 14 days for digestive inter- ventions (more than 5 days in the ICU) and 9 days for patients requiring surgery for genital neoplasms (more than 1 day in the ICU). Expenses for hospitalization, food, medication, sanitary materials, laboratory tests and imaging investigations were analysed. The costs of surgical reinterventions were not separately analysed.

Apart from the basic blood tests, C-reactive protein (CRP) and leucocytosis in the peritoneal drainage fluid were evaluated in patients with digestive interventions on days 1, 3 and 5 postoperatively. Peritoneal leukocyte count was performed by centrifugation in the urinalysis machine. The data obtained were correlated with the leukocyte count and haemoglobin value progression on the CBC. In patients with genital tumours, leukocyte count and haemoglobin value progression were monitored.

Clinical data collected from the patient (fever, dynamic ileus, intestinal occlusion, vomiting, increase in naso-gastric fluid volume and changes in appearance, peritoneal irritation signs, hepato-renal failure, tachyarrhythmias etc.) were correlated with paraclinical and imaging investigations.

All patients received antibiotics (cephalosporins) and pre- and postoperative thrombo-prophylaxis. Major complications (grades III-V according to Dindo-Clavien) required invasive treatment, ICU monitoring, and also increased hospital stay. These complications led to the allocation of additional budgetary resources within the hospital, also affecting the costs of the Surgery Clinic.

\section{Results}

The following tumour localizations were taken under supervision:

- Digestive (anastomoses \pm stomas) (120 patients):

- Stomach + small bowel 14.17\% (out of 254);

- Liver, MBD (main bile duct), pancreas $9.44 \%$ (out of 254 );

- Colorectal 23.62\% (out of 254);

- Genital (134 patients): 
- Cervix 27.55\% (out of 254);

- Uterus $11.02 \%$ (out of 254);

- Ovaries 14.17\% (out of 254).

Of the 254 patients, 201 had no postoperative complications (79.13\%). However, 53 patients presented various complications, representing 20.86\%. 31 patients $(12.20 \%)$ presented major complications (Table 1).

Of the 134 patients submitted to pelvic surgery, 9 (6.71\%) had major complications, accounting for $16.98 \%$ of the total complications. The 9 patients accounted for $3.5 \%$ of the total patients and accounted for $29.03 \%$ of major postoperative complications (Table 1).

Patients operated on at the level of the digestive tract were in a number 120 . Of these, $22(18.33 \%)$ had major complications representing $83.02 \%$ of the total complications. The 22 patients constituted $8.66 \%$ of the investigated patients and represented $70.96 \%$ of the major postoperative complications.

The postoperative mortality recorded for the entire group of 254 patients during hospitalization was of 6 patients, representing $2.36 \%(0.39 \%$ - genital and $1.96 \%$ - digestive respectively). Compared to the group with major complications, deaths represented $19.35 \%$ (3.22\% genital and $16.12 \%$ digestive) (Table 1). Other clinics $(1,3)$ report major postoperative complications ranging from $15 \%$ to $24 \%$, and mortality between $14 \%-15.3 \%$. In our lot, major complications were recorded in $12.30 \%$ of cases, and mortality in those with major complications was $19.35 \%$.

In the patients included in the study (254), 11 reinterventions $(4.33 \%)$ were required out of the entire group, 7 for patients submitted to surgery on the digestive tract $(5.83 \%)$ and 4 for genital area interventions in women $(2.98 \%)$. All these reinterventions required prolonged treatment in the ICU (13.57 days on average), increased hospital stay to an average of 24.28 days, and higher hospitalization costs: $21.046 \mathrm{RON}$ on average per reintervention (Tables 2, 3 and 4).

Of the 254 patients, 53 patients had various complications representing $20.86 \%$. 31 patients (12.20\%) experienced major complications. Costs of treatment for an oncological patient were on average (Table 4).

Table 1. Features of patients submitted to surgery

\begin{tabular}{|c|c|c|c|}
\hline Patients & Without complications & Minor complications & Major complications \\
\hline Number - 254 & $201(79.13 \%)$ & $22(8.66 \%)$ & $31(12.22 \%)$ \\
\hline Male - 68 & 53 & 6 & 11 \\
\hline Female - 186 & 150 & $\begin{array}{c}16 \\
\text { (9 genital, } 7 \text { digestive) }\end{array}$ & $\begin{array}{c}20 \\
\text { (9 genital, } 11 \text { digestive) }\end{array}$ \\
\hline Average age $=60.63$ years & $\begin{array}{l}63.2 \text { years - digestive } \\
58.45 \text { years - genital } \\
60.27 \text { years - general }\end{array}$ & $\begin{array}{c}64.7 \\
(62.2-\text { genital, } \\
67 \text { - digestive })\end{array}$ & $\begin{array}{c}61 \\
(59.44-\text { genital, } \\
61.59 \text { - digestive) }\end{array}$ \\
\hline \multirow[t]{6}{*}{ Surgical interventions } & Stomach + small bowel $=22$ & 4 & 10 \\
\hline & Liver-MBD, pancreas $=19$ & 2 & 3 \\
\hline & Colorectal $=44$ & 7 & 9 \\
\hline & Cervix $=64$ & 2 & 4 \\
\hline & Uterus $=23$ & 2 & 2 \\
\hline & Ovaries $=29$ & 5 & 3 \\
\hline Hospital stay (days) & 12 - digestive & 15.54 - digestive & 30.8 - digestive \\
\hline Total $=18,65$ & $\begin{array}{l}8,34-\text { genital } \\
\text { Total }=10.1\end{array}$ & $\begin{array}{l}\text { 18,5 - genital } \\
\text { Total = } 17.02\end{array}$ & $\begin{array}{l}26,88-\text { genital } \\
\text { Total }=28.84\end{array}$ \\
\hline $\begin{array}{l}\text { ICU stay (days) } \\
\text { Total }=7,16\end{array}$ & $\begin{array}{l}4.5 \text { - digestive } \\
1-\text { genital } \\
\text { Total }=2.75\end{array}$ & $\begin{array}{l}5.81 \text { - digestive } \\
5.2-\text { genital } \\
\text { Total }=5.5\end{array}$ & $\begin{array}{l}18 \text { - digestive } \\
8.49-\text { genital } \\
\text { Total }=13.24\end{array}$ \\
\hline Mortality $=6$ & 0 & 0 & $\begin{array}{l}5 \text { - digestive } \\
1 \text { - genital }\end{array}$ \\
\hline
\end{tabular}


Table 2. Postoperative complications

\begin{tabular}{|c|c|c|c|}
\hline Patient complications & Digestive & Genital & Total \\
\hline \multicolumn{4}{|l|}{ Specific postoperative complications } \\
\hline Postoperative haemorrhage & 2 & 3 & 5 \\
\hline Surgical wound seroma/abscess & 4 & 4 & 8 \\
\hline Intestinal fistula & 13 & 1 & 14 \\
\hline Intestinal occlusion & 2 & 1 & 3 \\
\hline Superior digestive haemorrhage & 4 & 0 & 4 \\
\hline Peritonitis & 3 & 0 & 3 \\
\hline Ascites & 1 & 0 & 1 \\
\hline Subphrenic abscess & 2 & 0 & 2 \\
\hline Pre- and retroperitoneal hematoma & 1 & 0 & 1 \\
\hline Sepsis, peritoneal abscess & 1 & 0 & 1 \\
\hline Metrorrhagia & 0 & 1 & 1 \\
\hline Surgical wound dehiscence - evisceration & 0 & 1 & 1 \\
\hline Total specific complications & 33 & 11 & 44 \\
\hline \multicolumn{4}{|l|}{ General complications } \\
\hline Bronchopneumonia/Acute Respiratory Failure & 4 & 0 & 4 \\
\hline Cardiac arrhythmia & 1 & 2 & 3 \\
\hline Thromboembolism & 0 & 1 & 1 \\
\hline Lower limb deep vein thrombosis & 0 & 1 & 1 \\
\hline Hepatic failure & 5 & 0 & 5 \\
\hline Urinary infection & 1 & 0 & 1 \\
\hline Pleurisy & 5 & 1 & 6 \\
\hline Acute renal failure & 3 & 4 & 7 \\
\hline Macroscopic haematuria & 1 & 1 & 2 \\
\hline Stroke & 1 & 0 & 1 \\
\hline Secondary anaemia & 7 & 5 & 12 \\
\hline Pericarditis & 1 & 0 & 1 \\
\hline MSOF- Multisystem organ failure & 2 & 1 & 3 \\
\hline Catheter thrombophlebitis & 0 & 1 & 1 \\
\hline Hyper K+ & 0 & 1 & 1 \\
\hline Diarrheic syndrome with Clostridium Difficile & 0 & 2 & 2 \\
\hline Total general complications & 31 & 20 & 51 \\
\hline Total complications & 64 & 31 & 95 \\
\hline Reintervention & 7 & 4 & 11 \\
\hline Death & 5 & 1 & 6 \\
\hline
\end{tabular}

\section{Discussions}

Major abdominal and pelvic oncological surgery (digestive and genital) involves the possible occurrence of complications. The timely tracing of severe complications entails a more prompt therapeutic approach, before changes implied by multiple organ failure occur. Frequently, these complications generate a true cascade of events, with a major impact on the patient's biological balance. If they overlap with an immunocompromised field, due to radio-chemotherapy, at an age with modest functional reserves, all the conditions for a poor outcome are outlined.

Going through the postoperative complications table (Table 2) one can observe their polymorphous nature. Thus, a number of 51 general complications (53.68\%) was recorded, compared to 44 complications specific to the surgical intervention (46.31\%). It should be noted that the ratio between these two groups of complications is approximately equal, and several complications may be reported in the same patient, both general and specific. Thus, the 53 patients with complications developed a number of 95 postoperative events. At the same time, a significantly higher rate of complications after digestive surgery was recorded compared to pelvic surgery. Moreover, the complications arising after digestive system surgery have a degree of

Table 3. Average ICU and hospital stay for patients submitted to surgery

\begin{tabular}{llcc}
\hline Interventions & Complications & ICU stay (days) & Hospital stay (days) \\
\hline Digestive & Without complications & 4.5 & 12 \\
& Major complications & 18 & 30.8 \\
Genital & Without complications & 1 & 8.34 \\
\hline & Major complications & 8.49 & 26.88 \\
\hline
\end{tabular}

Table 4. Average costs of surgery with and without major complications

\begin{tabular}{|c|c|c|}
\hline Interventions & Complications & Cost \\
\hline \multirow[t]{2}{*}{ Digestive } & Without complications & 7,542 RON \\
\hline & Major complications & 30,578 RON \\
\hline \multirow[t]{2}{*}{ Genital } & Without complications & $4,040.6$ RON \\
\hline & Major complications & $11,034.2 \mathrm{RON}$ \\
\hline \multirow[t]{2}{*}{ Average intervention cost } & Without complication & 5,791.3 RON \\
\hline & Major complications & 20,806 RON \\
\hline
\end{tabular}


severity that exceeds that of the complications after gynaecological interventions.

Diagnosis and treatment of these severe complications remain a challenge and are important in reducing morbidity and mortality. The occurrence of postoperative complications involved an increase in the number of laboratory tests, the introduction of additional investigations (CRP, leukocyte count from the peritoneal drainage fluid), additional imaging investigations (X-rays, ultrasound exam, CT), prolonged conservative treatment and / or surgical reinterventions, all leading to prolonged ICU and hospital stay. Thus, our study shows how postoperative complications, especially major ones (classified by DindoClavien), can significantly increase patient treatment costs.

In our patients, complications occurred in $20.86 \%$ of cases, out of which major ones represented about $12.20 \%$, a percentage similar to that reported by other clinics with similar pathology (1). Compared to major complications, deaths were $19.35 \%$ (3.22\% genital and $16.12 \%$ digestive). Other clinics $(1,3)$ report major postoperative complications ranging from $15 \%$ to $24 \%$, and mortality between $14 \%-15.3 \%$.

The occurrence of these complications led to an average increase of costs from 5,791.3 RON to $20,806 \mathrm{RON}, 3.5$ times higher compared to uncomplicated patients. A major impact of the costs of patients with major complications on the hospital budget was observed. It should be noted that patients who present a major postoperative complication may require continued outpatient treatment and / or home care, and in some of them present delays in returning to work, which can involve additional costs for society.

With regard to this, the study also aimed to search / associate laboratory and imaging investigations that would allow the discovery of specific complications and their early treatment. This could translate into fewer days of hospitalization (both in the ICU and on the ward postoperatively) and, therefore, lower hospital costs. The data obtained by us, as well as those in the literature, show that CRP may foreshadow the occurrence of a complication long before its clinical and imaging manifestation (1.5 days versus 4 days), allowing early diagnosis and aggressive treatment (6). For new digestive sutures we also introduced leukocyte count monitoring from peritoneal drainage fluid, along with CRP and CBC. Major abdominal and pelvic surgery sometimes involves extensive interventions, sometimes with multiple organ resections. These interventions predispose to incidents and intraoperative accidents, which can contribute to increased hospitalization costs (7).

Abdominal and pelvic surgical interventions for cancer require the administration of an injectable anticoagulant to prevent deep vein thrombosis (DVT) and its complications (thromboembolism). Data from the literature show that the incidence of thromboembolism was $4.89 \%$ in patients followed for 90 days postoperatively. Occurrence of DVT in patients undergoing major abdominal surgery resulted in a 1.5 -fold increase in hospitalization duration and a 2.8 -fold increase in total costs at 90 days postoperatively, compared to patients who did not develop this complication. Thus, effective prophylactic treatment of DVT is recommended to reduce the economic burden associated with major abdominal surgery. (8)

In terms of gynaecological interventions for cancer, the percentage of patients with major complications is 3 times lower than that observed in patients who underwent surgery at the level of the digestive tract $(6.71 \%$ versus $18.33 \%)$. On the other hand, complications following gynaecological surgery are of considerably smaller size and lower severity than those of digestive surgery. Good management of fast postoperative recovery, with the prevention and timely treatment of possible complications, is associated with low morbidity and a substantial reduction in hospitalization costs. $(9,10)$

Thoraco-abdominal X-ray and abdominopelvic ultrasound were the most used imaging investigations. CT was performed at the indication of a specialist (anaesthesia and intensive care specialist, surgeon, neurologist etc.), without the possibility of treatment of 
abdomino-pelvic septic complications through percutaneous drainage.

Any surgeon's dream is surgery without complications. Our endeavours and efforts are directed accordingly. All efforts are being made to achieve this goal. However, there are a number of variables that interfere with the patient's postoperative evolution, making complications possible: vascular field, preexisting septic factors, nutrition status, neoplasia, radio-chemotherapy, the magnitude of the surgical intervention, and others.

\section{Conclusions}

Postoperative complications in abdominal and pelvic oncological surgery occur in approximately $20.86 \%$ of patients and represent approximately $54 \%$ of the costs of patients undergoing these surgeries. Major complications were present in a percentage of $12.20 \%$, relative to the entire studied group, and increased patient costs by 3.5 times. Severe complications require emergency emplyment of exploration means needed to obtain early diagnosis and initiate prompt treatment.

We consider that the introduction into the diagnostic protocol of complications of CRP (C-Reactive Protein) and of leukocyte count from the peritoneal fluid, together with CBC, are useful for early diagnosis of postoperative complications. Abdomino-pelvic ultrasound and thoraco-abdominal radiography, which are cost-effective, could also contribute to these.

In the future, we are trying to introduce CRP determination and leukocyte count from the peritoneal fluid as a standard for early postoperative diagnosis of specific complications. CT scanning remains the most valuable method providing topographical data regarding the site of the complication, indicating the approach pathway: interventional CT or classic / laparoscopic surgical approach.
General postoperative complications do not fall into the surgeon's field of work, their diagnosis and resolution being in their entirety the responsibility of the intensive care physician. These complications may precede or may develop concurrently with complications specific to the surgical intervention.

The results we obtained provide an insight into the cost of hospitalization in oncological patients undergoing surgery. Establishing and applying a protocol aimed at early diagnosis and treatment of specific complications could lead to a decrease in morbidity, mortality, as well as in hospitalization costs.

\section{References}

1. Straatman J1, Cuesta MA, de Lange-de Klerk ES, van der Peet DL. Cost-analysis of complications after major abdominal surgery. Dig Surg. 2015; 32(2):150-6. doi: 10.1159/000371861.

2. Erekson EA, Yip SO, Ciarleglio MM, Fried TR. Postoperative complications after gynecologic surgery. Obstet Gynecol. 2011; 118(4):785-93. doi: 10.1097/AOG.0b013e31822dac5d.

3. Eappen S, Lane BH, Rosenberg B, Lipsitz SA, Sadoff D, Matheson $D$, et al. Relationship between occurrence of surgical complications and hospital finances. JAMA. 2013;309(15):1599-606. doi: 10.1001/jama.2013.2773.

4. Clavien PA, Barkun J, de Oliveira ML, Vauthey JN, Dindo D, Schulick RD, et al. The Clavien-Dindo classification of surgical complications: five-year experience. Ann Surg. 2009;250(2):18796. doi: 10.1097/ SLA.0b013e3181b13ca2.

5. Katayama H, Kurokawa Y, Nakamura K, Ito H, Kanemitsu Y, Masuda $\mathrm{N}$, et al. Extended Clavien-Dindo classification of surgical complications: Japan Clinical Oncology Group postoperative complications criteria. Surg Today. 2016;46(6):668-85. doi: 10.1007/s00595-0151236-x. Epub 2015 Aug 20.

6. Daams F, Luyer M, Lange JF. Colorectal anastomotic leakage: aspects of prevention, detection and treatment. World J Gastroenterol. 2013;19(15):2293-7. doi: 10.3748/ wjg.v19.i15.2293.

7. Garbens A, Goldenberg M, Wallis CJD, Tricco A, Grantcharov TP. The cost of intraoperative adverse events in abdominal and pelvic surgery: A systematic review. Am J Surg. 2018;215(1):163-170. doi: 10.1016/j.amjsurg.2017.06.025. Epub 2017 Jul 8.

8. Sakon M, Maehara Y, Kobayashi T, Kobayashi H, Shimazui T, Seo $\mathrm{N}$, et al. Economic Burden of Venous Thromboembolism in Patients Undergoing Major Abdominal Surgery. Value in Health Regional. 2015;6:73-79. DOI: https://doi.org/10.1016/j.vhri.2015.03.017

9. Kalogera E, Bakkum-Gamez JN, Jankowski CJ, Trabuco E, Lovely JK, Dhanorker S, et al. Enhanced recovery in gynecologic surgery.Obstet Gynecol. 2013;122(2 Pt 1):319-28. doi: 10.1097/ AOG.0b013e31829aa780.

10. Vaught AJ, Ozrazgat-Baslanti T, Javed A, Morgan L, Hobson CE, Bihorac A. Acute kidney injury in major gynaecological surgery: an observational study. BJOG. 2015;122(10):1340-8. doi: 10.1111/ 1471-0528.13026. Epub 2014 Aug 19. 